\title{
Seasonal Abundance of Two Species of Rotifers (Brachionus calyciflorus and Keratella tropica) in Kandy Lake, a Tropical Urban Water Body in Sri Lanka
}

\author{
E.I.L. SLVA*, M. EKANAYAKE AND K.M.B.C \\ KARUNATHLAKE \\ Institute of Fundamental Studies, Hantana Road, Kandy, Sri Lanka. \\ *Comesponding author (E-mail: sil@ifs.ac.lk)
}

\begin{abstract}
Monsoon-bound seasonal abundance of two species of rotifers (Brachionus calycifloras and Keratella tropica) was examined in relation to the population densities of Cladoceran zooplankton and phytoplankton and some limnlogical characteristics in Kandy Lake, a tropical urban water body in Sri Lanka, using standard techniques. Kandy Lake did not show marked seasonal variation influenced by the monsoons with respect to limnological parameters except for bicarbonate alkalinity and chlorophyll-a content. The population densities of Brachionus calyciflorus declined and Keratella tropica became dominant during the first inter-monsoon (MarchApril) when the abundance of total cladocerans and Microcystis aeruginosa, a cyanobacterial species with toxigenic strains, were high under relatively turbid conditions. Brachionus calyciflorus was re-established progressively during the subsequent season with decreasing populations of Microcystis aeruginosa and increasing densities of Aulacoseira granulata, a filamentous centric diatom, and Pediastrum simplex, a colony forming green algae.

The likely explanation for the marked suppression of Brachionus calyciflorus during the first inter-monsoon could be the abundance of toxin forming cyanobacteria strains of Microcystis aeruginosa or else a combined effect of Microcystis aenuginosa and interference competition resulting from high densities of total cladocerans under unfavourable environmental factors such as high turbidity.
\end{abstract}

\section{Introduction}

Rotifers are of fundamental importance in aquatic ecosystems due to their high efficiency in transforming primary production of phytoplankton and energy stored in bacteria into energy accessible by other organisms. They also show quick responses to environmental changes and are therefore considered as good indicators of water quality and trophic states (Sládecek 1983; Matveeva 1991). Rotifers, which are mainly confined to freshwater habitats, also show a cosmopolitan distribution 
perhaps due to different, highly adaptive life-history strategies (Gilbert 1985). The population densities of rotifers can be suppressed either by other pelagic zooplankton such as cladocerans when they compete for the same food resource or by direct interaction (Gilbert 1988). Filamentous and nonfilamentous cyanobacteria adversely affect rotifers by mechanically interfering with feeding or by producing toxins, which reduce longevity and fecundity (Gilbert and MacIssac 1991; Rothhaupt 1991).

It has been hypothesized that densities of rotifer populations in hydrologically dynamic reservoir ecosystems are regulated either by rapid throughput or predator pressure of zooplanktivorous fish (Duncan and Gulati 1983; Duncan 1984; Jayatunge 1986). The environmental factors or life-history strategies that determine the population abundance of planktonic rotifers in tropical aquatic habitats are poorly understood although attempts have been made to address their taxonony (Femando 1980a, b; Rajapaksa and Fernando 1982).

In the present study, the monsoon-bound seasonal variation in population densities of two species of rotifers (i.e. Brachionus calyciflorus and Keratella tropica) was studied with an especial emphasis on cladoceran populations, phytoplankton densities and basic limnological characteristics of an urban water body, Kandy Lake in Sri Lanka. Kandy Lake, a nonharvesting water body, which receives a fair amount of wastewater, has peculiar characteristics such as long retention time, and poor species diversity and high popuacion densities of fish. The primary objective of this study was to determine whether the seasonal abundance of two-rotifer species in Kandy Lake is influenced by cladocerans and toxic cyanobacteria (Microcystis aeruginosa).

\section{Study site}

Kandy Lake ( $7^{\circ} 18 \mathrm{~N} ; 80^{\circ} 39 \mathrm{E}$ at $\left.510 \mathrm{~m} \mathrm{MSL}\right)$, a water body of scenic beauty, located in the heart of the hill capital of Sri Lanka, Kandy, was constructed between 1810 and 1812 . It is 18 ha in area and $12.5 \mathrm{~m}$ in maximum depth and has a capacity of $0.348 \mathrm{MCM}$ with a perimeter of 3.05 $\mathrm{km}$. Two small brooks, which drain $2.85 \mathrm{~km}^{2}$ of the catchment, feed the Lake and water spills over only following heavy rains during the main rainy season (Oct - Dec). Evaporation losses are high during the dry months (Feb - Mar). The Lake has two morphologically distinct basins (deep and shallow) but has no prominent littoral zone and the entire perimeter is surrounded either by public roads or cement or concrete walls (Fig. 1). Erosion and subsequent transport of sediment over several decades has resulted in substantial siltation of about $1.5 \mathrm{~m}$ sediment thickness in the deeper basin. In addition, wastewater drains into the lake through 28 inlets including small hotels, hospitals, schools and temples. Being located adjoining to a major religious centre, the Temple of Tooth, fishing and bathing are prohibited in the lake and also the lake water is not utilized either for irrigation or for other domestic purposes. 
Except for the studies conducted on meso and macro aquatic fauna during 1979-1980 (De Silva and De Silva 1984) the Kandy Lake has not been subjected to a comprehensive limnological study. Dissanayake et al. (1982, 1986) reported that Kandy Lake has been enriched with $\mathbf{P}$ and $\mathrm{N}$ compounds and polluted with some heavy metals, A detailed limnological study commenced in 1997 revealed that the Lake was permanently stratified with a thick anoxic layer in the deeper basin (Silva 2003) and two species of phytoplankton, i,e., a diatom (Aulacoseira granulata) and a green algae (Pediastrum simplex), showed alternating monsoon-bound oscillations. A chronic cyanobacteria species $(M$, aeruginosa), which had some toxin producing strains (Jayatissa et al, pers. comm.) emerged as a bloom and formed into a thick scum in the shallow basin with the onset of the southwest monsoon in May 1999 (Silva 2003). The bloom disappeared within two months following the physical removal of scum and raising of the water level.

\section{Materials and Methods}

Zooplankton and phytoplankton were collected biweekly from January to December 2000 at four sampling sites of Kandy Lake (Fig. 1) using a Schindler Patalas sampler (15 l). Phytoplankton were collected using a $10 \mu \mathrm{m}$ meshed net for taxonomic studies. Water temperature, dissolved oxygen content, electrical conductivity, bicarbonate content, $\mathrm{pH}$ and Secchi depth were determined at each site in situ. Dissolved Oxygen content was measured using WTW Oxi 330 oxygen probe while electrical conductivity was measured using Jenway conductivity meter Model 4070. The bicarbonate alkalinity and $\mathrm{pH}$ were measured by alkalinity acidimetric titration and using a Jenway $3030 \mathrm{pH}$ meter respectively.

Water samples were collected from $1 \mathrm{~m}$ depths at each sampling site and transported immediately to the laboratory, which is located $1 \mathrm{~km}$ southwest of the Lake. In the laboratory, zooplankton samples were fixed in $5 \%$ formalin and phytoplankton samples were preserved in Lugol's solution. Sub samples of zooplankton were identified and counted using a Sedgwick rafter cell under a stereomicroscope. Water samples of $100 \mathrm{ml}$ each, fixed in Lugol's were processed for counting under an inverted microscope using a Sedgwick rafter cell. A known volume of water sample was filtered through GFC filter papers and chlorophyll-a content was determined (Marker et al. 1980). The least squared technique of regression was used to compare the relationship between chlorophyll-a content and Secchi disk visibility. The significance of the regression line was tested by analysis of variance (F-statistics). Significance of the seasonal variability of environmental parameters was examined using analysis of variance (oneway ANOVA) and the inter-relationship between populations was tested using a multiple range test (SNK procedure). 


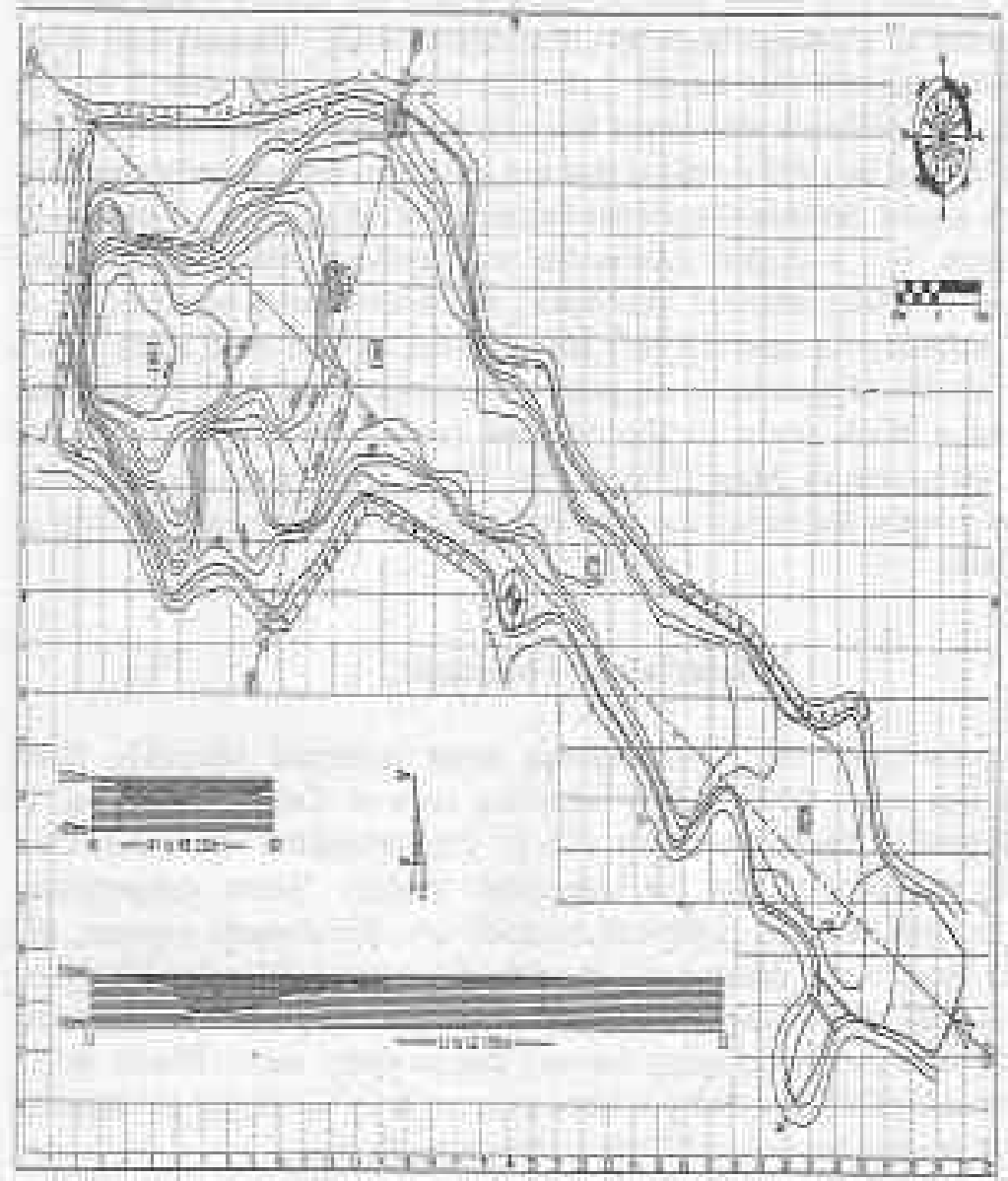

Figure 1. Map of the Kandy Lake showing sampling sites (A-D: Sampling sites).

\section{Results}

The magnitude and distribution of rainfall in the watershed of the Lake was more or less similar during four monsoon-defined seasons i.e., Dec-Feb, northeast monsoon (NEM); Mar-Apr, first inter-monsoon (FIM); May-Sep, southwest monsoon (SWM) and Oct-Nov, second inter-monsoon (SIM) in 2000 (Table 1). Daytime surface water temperature ranged between $26.0^{\circ} \mathrm{C}$ and $28.0^{\circ} \mathrm{C}$ and electrical conductivity varied between 212 $\mu \mathrm{S} \mathrm{cm} ~^{-1}$ and $239 \mu \mathrm{S} \mathrm{cm}^{-1}$ during the study period with no significant seasonal variation ( $\mathrm{p}>0.05$ ) (Table 1 ). The seasonal change in $\mathrm{pH}$ also showed a similar pattern but it varied between 6.96 and 8.61 and the widest range was recorded during the southwest monsoon (Table 1). The mean 
value of bicurbonate alkalinity ihowed a significant seasonal variation ( $\mathrm{p}<0.05$ ) with the lowest $\left(11 \mathrm{mg} \mathrm{I}^{-1}\right)$ and the highest $\left(119 \mathrm{mg} \mathrm{I^{3 }}\right)$ being during the first inter-monsoon and southwest monson respectively (Table 1). The mean seasonal value of Secchi depth was lowest $(81 \mathrm{~cm})$ during the first inter-monscon and it was highest $(121 \mathrm{~cm})$ during the southwest monsoon. One-way ANOVA showed no significant seasonal variation in Secchi disk visibility ( $\mathrm{p}>0.05$ ) (Table 1). However, chlorophyll-a content showed a significant seasonal variation $(\mathrm{p}<0.05$ ) and the seusonal mean was highest $\left(31.0 \mathrm{~kg}^{-1}\right)$ during the first inter-monsoon, which is more or less similar to that of the value computed for $\left(29 \mathrm{~kg}^{-1}\right)$ second inter-monsoon (Tuble 1). The mean seasonal chlorophyll-1 content was lowest $\left(20 \mathrm{\mu g}^{-1}\right)$ during the southwest monsoon und it was not siguificantly different from the value computed for the northeast monsoon $\left(23 \mu \mathrm{gl} \mathrm{I}^{\mathrm{H}}\right)$ aceording to oneway ANOVA (SNK test).

Table 1. Monsoon defined mean seasonal values ( \pm SD) of some environmental characteristics of Kandy Lake during the study period (JanDec 2000). NEM - North-east monsoon; FIM - First intermonsoon; SWM - South-west monsoon; SIM - Second intermonsoon; Prob - Probability level.

\begin{tabular}{|c|c|c|c|c|c|c|}
\hline Parameter & NEM & $\overline{\mathrm{FIM}}$ & SWM & SחM & F-ratio & $\overline{\text { Prob }}$ \\
\hline $\begin{array}{l}\text { Rainfall } \\
\text { Mm }\end{array}$ & 371 & 349 & 358 & 442 & & \\
\hline $\begin{array}{l}\text { No of rainy } \\
\text { days }\end{array}$ & 08 & 08 & 06 & 06 & & \\
\hline $\begin{array}{l}\text { Temperature } \\
{ }^{\circ} \mathrm{C}\end{array}$ & $\begin{array}{l}26.9 \\
\pm 0.75\end{array}$ & $\begin{array}{l}27.5 \pm \\
1.73\end{array}$ & $\begin{array}{l}27.4 \pm 1 . \\
99\end{array}$ & $\begin{array}{l}26,9 \pm 1 . \\
31\end{array}$ & 0.262 & 0.852 \\
\hline $\begin{array}{l}\mathrm{EC} \\
\mu \mathrm{S} \mathrm{cm}^{-1}\end{array}$ & $\begin{array}{l}231 \\
\pm 3.47\end{array}$ & $\begin{array}{l}225 \pm \\
9.52\end{array}$ & $\begin{array}{l}231 \pm \\
4.82\end{array}$ & $\begin{array}{l}230 \pm \\
402\end{array}$ & 0.880 & 0.474 \\
\hline $\mathrm{PH}$ & $\begin{array}{l}7.68 \\
\pm 0.22\end{array}$ & $\begin{array}{l}8.15 \pm \\
031\end{array}$ & $\begin{array}{l}7.73 \pm \\
0.53\end{array}$ & $\begin{array}{l}7.82 \pm \\
0.24\end{array}$ & 1.348 & 0.296 \\
\hline $\begin{array}{l}\text { Alkalinity } \\
\mathrm{mg} \mathrm{I}^{-1}\end{array}$ & $\begin{array}{l}114 \\
\pm 4.21\end{array}$ & $\begin{array}{l}111 \pm \\
5.49\end{array}$ & $\begin{array}{l}119 \pm 2.8 \\
6\end{array}$ & $\begin{array}{l}117 \pm 1.6 \\
4\end{array}$ & 5.603 & 0.009 \\
\hline $\begin{array}{l}\text { Secchi } \\
\text { Depth }\end{array}$ & $\begin{array}{l}119 \\
\pm 29\end{array}$ & $\begin{array}{l}81 \pm \\
304\end{array}$ & $\begin{array}{l}121 \pm \\
14.4\end{array}$ & $\begin{array}{l}113 \pm \\
136\end{array}$ & 3.164 & 0.055 \\
\hline $\begin{array}{l}\mathrm{Cm} \\
\mathrm{Chl}-\mathrm{a} \\
\mu \mathrm{g} \mathrm{l}^{-1}\end{array}$ & $\begin{array}{l}23 \\
\pm 12.1\end{array}$ & $\begin{array}{l}31.0 \pm \\
79\end{array}$ & $20 \pm 3.1$ & $\begin{array}{l}29 \pm \\
0.97\end{array}$ & 8.173 & 0.001 \\
\hline
\end{tabular}

Zooplankton were dominated by rotifers with only fow species of cyclopoid copepods and cladocerans present (Table 2). Five species of copepods belonging to four genera were identified from Kandy Lake during the study period. Phyllodiaptomas annae was the most widely distributod and abundant zopepod found during the study period: However, it was not 


\section{E.L.L. Silva et al,}

present in the samples in one occasion during the first inter-monsoon. The density of $P$. annae was relatively low during the second inter-monsoon. Merocyclops thermocyclopidus also occurred in relatively lurge numbers except during the second inter-monsoon. Of the five common copepods found in Kandy Lake (Tuble 2), deasities of Cyclops pracimas. Thermocyclops decipans and Thermoryciaps crassus were relatively low.

Table 2. The relative abundance (number per litre) of zooplankton species found in the Kandy Lake during four monsoon bound seasons in 2000. Abbreviations are as given in Table 1.

\begin{tabular}{lcccc}
\hline Species Name & NEM & FIM & SWM & SIM \\
\cline { 2 - 5 } Cladocera & & & & \\
Ceriodaphnia cornuta & 8 & 8 & 4 & 4 \\
Diaphanosoma exisum & 2 & 5 & 4 & 3 \\
Diaphanosoma sarsi & 7 & 6 & 3 & 1 \\
Diaphanosoma modiglini & 12 & 14 & 20 & 9 \\
Moina micnura & 11 & 12 & 6 & 5 \\
Copepoda & & & & \\
Cyclops pracinus & 18 & 9 & 6 & 1 \\
Mesocyclops & & & & \\
thermocylopidus & 24 & 13 & 12 & 3 \\
Phyllodiaptomus annae & 37 & 19 & 12 & 6 \\
Thermocyclops crassus & 6 & 4 & 2 & 1 \\
Thermocyclops decipans & 5 & 6 & 8 & 9 \\
& & & & \\
Nauplii & & & & \\
Nauplius Larvae & 52 & 43 & 27 & 9 \\
& & & & \\
Rotifers & & & & \\
Asplachna brightwelli & 12 & 7 & 2 & 1 \\
Brachionus calyciflorus & 32 & 1 & 23 & 17 \\
Brachionus donneri & 0 & 1 & 2 & 0 \\
Brachionus falcatus & 40 & 50 & 17 & 21 \\
Brachionus forficula & 0 & 33 & 6 & 10 \\
Filina terminalis & 2 & 2 & 1 & 1 \\
Horella brehmi & 10 & 6 & 1 & 1 \\
Keratella tropica & 10 & 43 & 10 & 6 \\
Testudinella elliptica & 0 & 0 & 0 & 0 \\
Tricocerca chattoni & 2 & 9 & 2 & 1 \\
\hline & & & &
\end{tabular}


Kandy Lake had five species of cladocerans that belong to three genera namely Ceriodaphnia, Diaphanosoma and Moina (Table 2). Of the genus Diaphanosoma, D. modiglini occurred in relatively large numbers during the study period. The two other species of the genus Diaphanosoma (D. sarsi and D. exisum) along with Moina micrura and Ceriodaphnia cornuta were found in relatively low numbers. With respect to rotifers there were ten species belonging to seven genera (i.e. Asplachna, Brachionus, Filina, Horella, Keratella, Testudinella and Tricocerca (Table 2). Of the genus Brachionus, B. falcatus was the dominant species found throughout the study period $v$ hereas $B$. calyciflorus was found in relatively large numbers except during the first inter-monsoon. The relative density of Brachionus forficula and $K$. tropica were high during the first inter monsoon. B. donneri and Testudinella elliptica were found only occasionally. The densities of other species of rotifers (Filina terminalis, Horella brehmi, $K$. tropica, and Tricocerca chattoni) were relatively low during the four seasons.

Thirty-seven species of phytoplankton were identified from the Kandy Lake during the study period (Table 3). Cyanophyceae was the dominant phytoplankton group and included mainly non-nitrogen fixing forms such as Microcystis aeruginosa and Merismopedia punctata. Of the diatoms, Aulacoseira granulata was dominant and the most widely distributed species. Among the green algae, 14 species were identified. Desmids were represented only by three genera (Closterium, Cosmerium and Staurastrum). Three species namely, A. granulata (a centric diatorn), Pediastrum simplex (a green algae) and $M$. aeruginosa (a cyanobacteria) were seasonally dominant, $M$. punctata (cyanobacteria) was also found in moderately high numbers throughout the year.

Figure 2 compares the relative abundance of $B$. calyciftorus, $K$. tropica and total rotifers with the relative abundance of the dominant phytoplankton species. The relative abundance of $B$. calyciflorus was lowest during the first inter-monsoon when $M$, aeruginosa population was highest. $B$. calyciflorus became progressively abundant from the southwest monsoon to the northeast monsoon in conjunction with the alternating oscillation of A. granulata and $P$. simplex in the phytoplankton assemblage (Fig. 2). When B. calyciflorus declined, $K$. tropica became the dominant species. Figure 3 shows the relative abundance of $B$. calyciflorus and $K$. tropica in relation to the abundance of total cladocerans and $M$. aeruginosa. There was a marked decline in B. calyciflonus during the first intermonsoon when the relative abundance of both total cladocerans and $M$. aeruginosa were high and $K$. tropica became the dominant rotifer. $B$. calyciflorus became dominant over $K$. tropica again when the abundance of $M$, aeruginosa and total cladocerans population were relatively low during the southwest monsoon and second inter-monsoon. Figure 4 depicts the distribution pattern of $B$. calyciflorus and $K$ tropica in relation to chlorophyll-a concentration in Kandy Lake. There is a clear relationship 
Table 3. List of phytoplankton species found in Kandy Lake during the study period (d-dominant; m-moderate; r-rare; NEM - Northeast monsoon; FIM - First Intermonsooon; SWM- Southwest Monsoon; SIM- Second Intermonsoon).

\begin{tabular}{|c|c|c|c|c|}
\hline Species Name & NEM & FIM & SWM & SIM \\
\hline \multicolumn{5}{|l|}{ Cyanophyceae } \\
\hline Anabaenopsis raciborskii & $\mathrm{R}$ & M & r & I \\
\hline Anabaenopsis sp. 2 & $\mathrm{R}$ & $\mathrm{M}$ & r & $\mathbf{r}$ \\
\hline Anabaenopsis sp. 3 & $\mathrm{R}$ & $\mathrm{R}$ & r & $\mathrm{r}$ \\
\hline Chroococcus limneticus & $\mathbf{R}$ & M & r & r \\
\hline Chroococcus sp. 2 & $\mathrm{R}$ & $\mathrm{R}$ & r & r \\
\hline Cylindrospermopsis sp. & $\mathbf{R}$ & $M$ & r & I \\
\hline Merismopedia punctata & M & M & $\mathrm{m}$ & $\mathrm{m}$ \\
\hline Microcystis aenuginosa & $\mathrm{D}$ & D & d & d \\
\hline Microcystis flosaquae & $\mathrm{R}$ & M & I & $\mathbf{r}$ \\
\hline Microcystis wesenbergii & M & $\mathrm{M}$ & $\mathrm{m}$ & $\mathrm{m}$ \\
\hline Oscillatoria $\mathrm{sp}$ & $\mathrm{R}$ & $\mathrm{M}$ & $\mathrm{r}$ & I \\
\hline Rhaphidiopsis sp. & $\mathbf{R}$ & $\mathrm{R}$ & r & $\mathrm{r}$ \\
\hline Spirulina sp. & - & $\mathrm{R}$ & - & - \\
\hline \multicolumn{5}{|l|}{ Diatomophyceae } \\
\hline Aulacoseira granulata & $\mathrm{D}$ & D & d & d \\
\hline Coelastrum sp. & $\mathrm{R}$ & M & r & r \\
\hline Cyclotella sp. & $\mathrm{R}$ & M & I & $\mathbf{r}$ \\
\hline Cymbella sp. & $\mathrm{R}$ & $\mathrm{M}$ & I & $=$ \\
\hline Navicula sp. & $\mathrm{R}$ & $\mathbf{R}$ & $\mathbf{r}$ & I \\
\hline Pinnularia sp. & $\mathrm{R}$ & $\mathbf{R}$ & I & r \\
\hline Rhizosolenia sp. & $\mathrm{R}$ & $\mathbf{R}$ & r & r \\
\hline \multicolumn{5}{|l|}{ Chlorophyceae } \\
\hline Ankistrodesmus sp. & $\mathrm{R}$ & $\mathrm{R}$ & $\mathrm{r}$ & $\mathrm{r}$ \\
\hline Centritractus sp. & $\mathrm{R}$ & $\mathrm{R}$ & I & $\mathrm{T}$ \\
\hline Dictyosphaerium sp. & $\mathrm{R}$ & $\mathrm{R}$ & I & $\mathrm{r}$ \\
\hline Golenkinia radita & $\mathrm{R}$ & $\mathrm{R}$ & I & r \\
\hline Kirchneriella sp. & $\mathrm{R}$ & $\mathrm{R}$ & $\tau$ & r \\
\hline Mallomonas sp. & $\mathrm{R}$ & $\mathrm{R}$ & r & $\mathbf{r}$ \\
\hline Monorophidium sp. & $\mathrm{R}$ & $\mathbf{R}$ & $r$ & $\mathbf{I}$ \\
\hline Oocystis sp. & $\mathrm{R}$ & $\mathbf{R}$ & I & $\mathbf{I}$ \\
\hline Pediastrum simplex & D & $\mathrm{D}$ & d & $\mathrm{D}$ \\
\hline Scenedesmus sp. & $\mathrm{R}$ & $\mathbf{R}$ & $r$ & $\mathbf{R}$ \\
\hline Spyrogyra sp. & $\mathrm{R}$ & $\mathrm{R}$ & r & $\mathrm{R}$ \\
\hline Tetraedron limneticum & $\mathbf{R}$ & $\mathrm{R}$ & r & $\mathrm{R}$ \\
\hline
\end{tabular}


Rotifers in Kandy Lake

Table 3 (Continued)

\begin{tabular}{|c|c|c|c|c|}
\hline Species Name & NEM & FIM & SWM & SIM \\
\hline \multicolumn{5}{|l|}{ Zygnemaphyceae } \\
\hline Closterium sp. & $\mathbf{R}$ & $\mathbf{R}$ & $r$ & $\mathbf{r}$ \\
\hline Cosmarium sp. & $\mathbf{R}$ & $\mathbf{R}$ & I & $\mathbf{r}$ \\
\hline Staurastrum rotula & $\mathbf{R}$ & $\mathbf{R}$ & r & I \\
\hline Staurastrum sp. 2 & $\mathbf{R}$ & $\mathbf{R}$ & I & I \\
\hline Stauastrum sp. 3 & $\mathrm{R}$ & $\mathrm{R}$ & I & I \\
\hline \multicolumn{5}{|l|}{ Euglenophyceae } \\
\hline Euglena sp. & $\mathrm{R}$ & M & r & $\mathrm{r}$ \\
\hline Phacus sp. & $\mathrm{R}$ & $\mathrm{M}$ & $1 T$ & $\mathbf{I}$ \\
\hline
\end{tabular}

between the relative abundance of two rotifers and chlorophyll-a (chl-a) concentration. $B$. calyciflonus shows a marked decrease in abundance with increasing chl-a concentration whereas the abundance of $K$. tropica is inversely related with chl-a concentration.

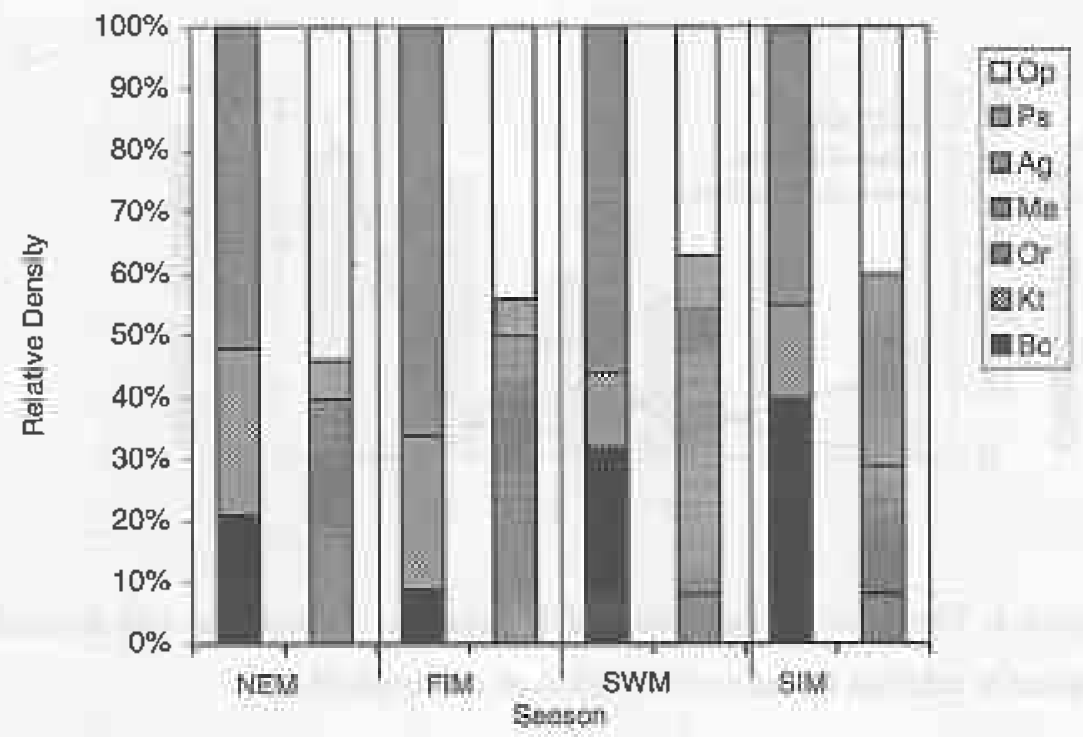

Figure 2. The relative abundance of Brachionus calyciflorus (Bc), Keratella tropica (Kt) and total rotifers (Or) with the relative abundance of Microcystis aeruginosa (Ma), Pediastrum simplex (Ps), Aulacoseira granulata $(\mathrm{Ag})$ and other plankton $(\mathrm{Op})$. 


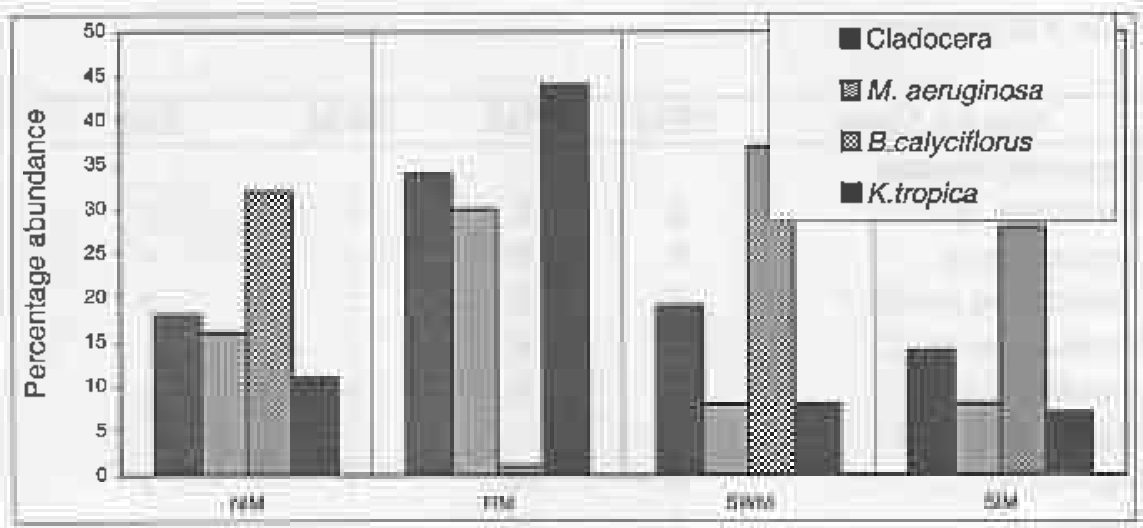

Figure 3. The relative abundance of Brachionus calyciflorus and Keratella tropica in relation to the abundance of total cladocerans and Microcystis aeruginosa.

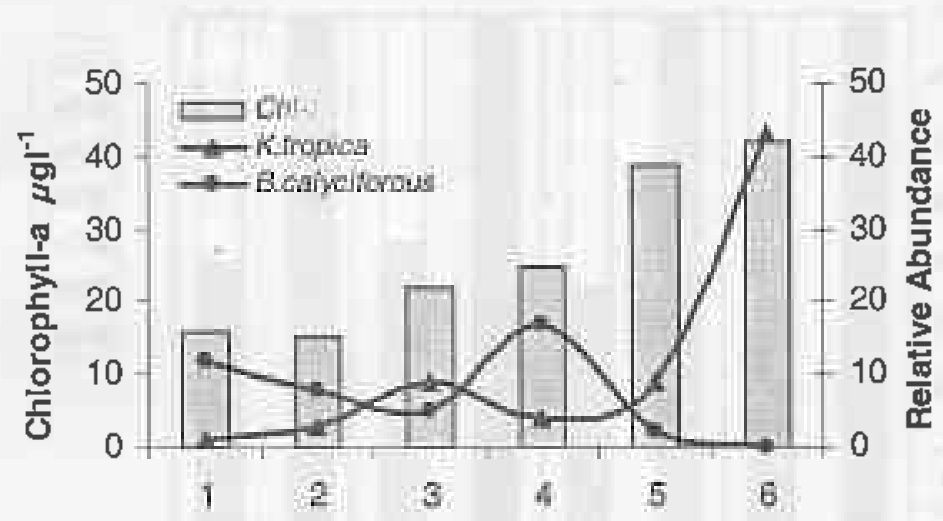

Figure 4. The relative abundance of Brachionus calyciflorus and Keratella tropica in relation to the concentration of chlorophyll-a

\section{Discussion}

Although it experiences weather and climate typical to the wet zone of Sri Lanka, Kandy Lake did not show a marked monsoon-bound seasonal variation in environmental parameters (i.e. Temperature, $\mathrm{pH}, \mathrm{EC}$ and transparency) except for bicarbonate alkalinity and chlorophyll-a content during the study period, perhaps due to the uniform distribution of rainfall throughout the year 2000. Silva and Davies (1987) showed a significant monsoon bound seasonal variation in phytoplankton primary productivity 
and related parameters in irrigation reservoirs in Sri Lanka. However bicarbonate alkalinity was significantly low daring the first inter-monsoon. Low bicarbonate alkalinity, high $\mathrm{pH}$, low transparency, coupled with optimum nutrient conditions (low $\mathrm{N}$ and high $\mathrm{P}$ ) promotes the growth of toxic cyanobacteria such as $M$. aeruginasa (Jacoby et al 2000). There is evidence that $M$. aeruginasa with toxigenic strains emerged in Kandy Lake in May 1999 under low light attenuation when N:P ratio was extremely low (Silva 2003). Although chlorophyll-a and Secchi disk transparency were negatively correlated, the outliers resulting from inorganic turbidity may weaken the significance of the relationship. Sudden and intermittent changes in turbidity may have significant effects on both zooplankton communities and phytoplankton assemblages. Rotifers belonging to family Brachionidae are strongly associated with environmental factors such as temperature, water flow, $\mathrm{pH}$, salinity, alkalinity, mineralization, transperency etc. (De Manuel 1991). The species diversity of zooplankton, especially, planktonic crustaceans in Sri Lankan reservoirs is smafler than that found in temperate regions. Rotifers dominated by the genus Brachionus, are common in pelagic zooplankton conmunities in Sri Lankan reservoirs (Fermando 1980a; Rajapaksa and Fernándo 1982; Jayatunge 1986). Further, it has been emphasized that rotifer population densities in hydrologically dynamic reservoir ecosystems are regulated either by rapid throughput or predator pressure of zooplanktivorous fish (Duncan 1984; Duncan and Gulati 1983; Jayaunge 1986). The changes in rotifer population in Parakrama Samudraya in Sri Lanka, a hydrologically dynamic irrigation reservoir were attributed to the flushing rate and predator pressure of two zooplanktivorous fish species namely Hemirhamphus limbatus and Ehirava fluviatilis (Duncan 1984). Jayatunge (1986) found that zooplankton population densities and composition were regulated by a hydraulic regime of the Kalawewa reservoir in Sri Lanka. The situation in Kandy Lake is quite different compared to irrigation reservoirs. Kandy Lake has a long retention time, free from zooplanktivorous fish and the fish fauna is dominated by cichlids (mainly Oreochromis mossambicus and $O$. niloticus) due to its stagnant nature and non-fishing practices. In shallow ponds where high densities of fish occur, the zooplankton may be almost exclusively Rotifera. This situation has been observed in ponds with high density of tilapia in Costa Rica (Hurbet and Mulla 1981). A similar result was reported by Moitra and Mukhejee (1972) in Calcutta fishponds. Duncan (1983) showed high population densities of rotifers during low water level in Parakrama Samudra, In Parakrama Samudra, high density of rotifers was observed in February 1978 (dry season) during high water level and also during a later period in 1980 during the October-November rainy season (Duncan 1983).

It has been shown that rotifer populations can be negatively affected by toxic or filamentous cyanobacteria (Seal et al. 1993). The $M$. aenuginosa found in Kandy Lake contained toxigenic strains (Dr. L.P. Jayatissa and Prof. Rudi Hofer, pers. cornm, and it has been observed that 
$B$. calyciflorus ingested $M$. aeruginosa cells in fresh phytoplankton samples. High concentration of chl-a in Kandy lake is mainly due to the occurence of high densities of $M$. aeruginosa colonies in the phytopklankton assemblage (Silva 2003). Attempts have been made to correlate rotifer densities and their species compositions to trophic status of the water body in many instances (Radwan 1976; Sládecek 1983; Karabin 1985). The toxigenic Microcystis that stopped the food intake in Daphnia magna did not inhibit feeding in Brachionus rubens and was ingested by the rotifers at a rate comparable to Monoraphidium, (Rothhaupt [991). $B$. rubens cultured with $M$. aeruginosa died faster than non-fed controls. The rigid filaments of Cylindrospermopsis were not ingested by $B$. rubens. Therefore B. calyciflorus in Kandy Lake may be negatively affected by biochemical (toxin) properties of M. aeruginosa as shown by Matveeva (1991). Relationship between trophic status and rotifer composition may be attributed to relative abundance of toxin forming cyanobacteria as seen during this study. Annual range of chlorophyll-a and its seasonal variation in Kandy Lake showed an inter-monsoonal trophic shift associated with other environmental parameters. However, Kandy Lake is eutrophic but the magnitude of trophy varies over the seasons as a result of rainfall.

Large Cladocerans can compete out or suppress rotifer species, indirectly by exploiting shared food resources or by direct interaction (Gillbert 1988; Dawidowicz and Pijanowska 1991; Modenuitti et al. 1993). When the population density of $B$. calyciftorus declined in Kandy Lake during the first inter-monsoon the total Cladoceran density was high, in addition to the occurrence of dense colonies of $M$. aeruginosa. It seems that $K$ tropica is neither ingesting toxigenic cyanobacteria cells nor competing for the same food resource with Cladocerans. When conditions of lakes are constant rotifer communities may remain invariable for decades and a considerable increase in trophy has been observed to result in the extinction of some species and emergence of others (Dawidowicz and Pijanowska 1991, Modenutti et al. 1993) However, likely interpretation of changes in seasonal distribution of planktonic rotifer populations are complex and generalization is difficult to make. The seasonal changes in rotifer densities and composition have been correlated to temperature in warm temperate regions where variations are very common. Species develop maxima in summer, specially in late summer, with the development of certain blue green algal population. However, very little is known about seasonal succession among rotifers and their inter- and intra-specific competition in the tropics.

The most likely reason for the apparent suppression of $B$. calyciflorus during the first inter-monsoon could be the abundance of toxigenic strains of $M$. aenuginosa or else a combined effect of $M$. aeruginosa and interference competition resulting from high densities of total Cladocerans under unfavourable environmental conditions such as high turbidity. 


\section{Acknowledgements}

The Financial assistance provided by the Institute of Fundamental Studies is gratefully acknowledged. We would also like to thank Mr. Namal Athukorala and Ms. Irangani Thumpela for field assistance and laboratory analysis, Ms. Thushara Malavisooriya and Ms. Indika Meedeniya for typing the manuscript and Ms. Indika Meedeniya for preparing the computer graphics and Dr. (Ms.) Shirani Nathaneal for reading the draft manuscript.

\section{References}

Dawidowicz, P. \& J. Pijanowska 1991.

Competitive interactions between cladocerans and rotifers: An experimental study. Internationale Verenigung für Theoritische and Angenwandte Limnologie 24: 917-920.

De Manuel, J. 1991.

Distribution of Brachionidae (Rotifera: Monogononta) in Spanish reservoirs. Internationale Verenigung für Theoritische and Angenwandte Limnologie 24: 2741-2744.

De Silva, P.K. \& K.H.G.M. De Silva, 1984.

An ecological study of the meso and macro fauna of the littoral region of Lake Kandy in Sri Lanka. Archiv für Hydrobiologie 102: 53-72.

Dissanayake, C.B., A. Senarathne, S.V.R. Weerasooriya \& S.H.G. De Silva 1982.

The Environmental pollution of Kandy Lake in Sri Lanka: A case study from Sri Lanka. Environment International 17: 343-351.

Dissanayake, C.B., A.M. Rohan Bandara \& S.V.R. Weerasooriya 1986.

Heavy metal abundance in the Kandy Lake: An environmental case study from Sri Lanka. Environmental Geology and Water Science 10(2): 81-88.

Duncan, A. 1984.

Assessment of factors influencing the composition, body size and tumover rate of zooplankton in Parakrama Samudra, an irrigation reservoir in Sri Lanka. Hydrobiologia 113: 201-215.

Duncan, A. \& R.D. Gulati 1983.

Feeding studies with natural food particles on tropical species of plankton rotifers. In: Limnology of Parakrama Samudra - Sri Lanka. (F. Schiemer ed.). W. Junk. The Hague, pp. 117-125.

Fernando, C.H. 1980a.

The freshwater zooplankton of Sri Lanka with a discussion of tropical freshwater zooplankton composition. Internationale Revue der Gesmten Hydrobiologie 65: 85-125. 


\section{E.I.L. Silva et al.}

Fernando; C.H. 1980b.

The species and size composition of tropical freshwater zooplankton with special reference to the oriental region (South East Asia). Internationale Revue der Gesmten Hydrobiologie 65 : 411-426.

Gilbert, J.J. 1985.

Competition between rotifers and Daphnia. Ecology 66: 1943-1950.

Gilbert, J.J. 1988.

Suppression of rotifer populations by Daphnia: A review of the evidence, the mechanisms, and the effects on zooplankton community structure. Limnology and Oceanography 33: 12861303.

Gilbert, J.J. \& R.S. Stemberger 1985.

Control of Keratella populations by interference competition from Daphnia. Limnology and Oceanography 30: 180-188.

Gilbert, J.J. \& .H.J. MacIssac 1991.

Discrimination between exploitative and interference competition between Cladocera and Keratella cochlearis. Ecology 72: 924-937

Hurlbert, S. H. \& M. S Mulla 1981.

Impacts of mosquitofish (Gambusia affinis) predation on plankton communities. Hydrobiologia 83: 125-151.

Jacoby, J.M., D.C. Collier, E.B. Welch, F.J. Hardy \& M. Crayton 2000.

Environmental factors associated with a toxic bloom of Microcystis aeruginosa. Canadian Joumal of Fisheries and Aquatic Sciences 57: 231-240.

Jayatunge, Y.N.A. 1986.

The influence of food and temperature on the life cycle characteristics of tropical cladoceran species from Kalawewa Reservoir, Sri Lanka. Unpublished $\mathrm{PhD}$ Thesis. University of London. 410 pp.

Karabin, A. 1985.

Pelagic zooplankton (Rotifera and Crustacea) variation in the process of lake eutrophication. 1. Structural and quantitative features. Polish Journal of Ecology 33: 567-616

Marker, A.F.H., C A. Crowther \& R.J.M. Gunn 1980.

Methanol and acetone as solvent for estimating chalorophyll-a and phaeopigments by spctrophotomtry. Archiv für Hydorbiologie (Supplement) 14: 52-69

Matveeva, L.K. 1991.

Can pelagic rotifers be used as indicators of lake trophic state Internationale Verenigung für Theoritische and Angenwandte Limnologie 24: 2761-2763.

Modenutti, B.E., E.G. Balseiro \& C.P. Queimalińos 1993.

Can small cladocerans depress rotifer density? Internationale Verenigung fürTheoritische and Angenwandte Limnologie 25: 947. 
Moitra, S.K.A. \& S.K. Mukhejee 1972.

Studies on the freshwater plankton of a fish pond at Kalyani, West Bengal. Vest. Čs. Spol. Zool. 36: 24-28.

Radwan, S. 1976.

Planktonic rotifers as indicators of lake trophy. Ann. UMC-SC 31:

227-235.

Rajapaksa, R \& C.H. Fernando 1982.

Cladocera of Sri Lanka with remarks on some species. Hydrobiologia 94: 49-69.

Rothhaupt, K.O. 1991.

The influence of toxic and filamentous blue-green algae on feeding and population growth of the rotifer Brachionus rubens. Internationale Verenigung für Theoritische and Angenwandte Limnologie 24: 2760.

Seal, D.B., M.E. Boraas \& B. Horton 1993.

Use of semi-continuous culture methods for examining competitive outcome between two freshwater rotifers, genus Brachinus growing on single algal resource In: Plankton regulation dynamics: experiments and models in rotifer continuous cultures (N. Walz ed). Elsevier, Amsterdam, 161-167 pp.

Silva, E.I.L. \& R.W. Davies, 1987.

The seasonality of monsoonal primary productivity in Sri Lanka. Hydrobiologia 150: 165-75.

Silva, E.I.L 2003.

Emergence of Microcystis aeruginosa bloom in an urban water body, Kandy Lake in Sri Lanka. Current Science 26: 00-00 (in press)

Sládecek, V. 1983.

Rotifers as indicator of water quality. Hydrobiologia 100: 169-201. 